\title{
ASSESSMENT OF SCHOOL RECORD MANAGEMENT IN SECONDARY SCHOOLS IN FEDERAL CAPITAL TERRITORY
}

\author{
${ }^{* 1}$ Odeniyi, O. A. and ${ }^{2}$ Adeyanju, A. S.
}

*Department of Education Administration and Planning, National Open University, Abuja, Nigeria

*Phone: +2347033449254*Email: dknladeyanju@gmail.com

\begin{abstract}
The study was carried out with the purpose of assessing school record management in FCT secondary schools. Record management is the area of administrative management that is concerned with achieving economy and efficiency in the creation, maintenance, use and disposal of records of an organization throughout its life cycle. Implementing good record management practices in schools would provide information for educational planners and administrators, serves as historical source for documenting history of the school. School records comprise all existing and accessible records, books, files and other documents containing useful information that relates to what goes on in the school system They are evaluation tools for accessing progress made by schools and also show evidence of compliance with legislative laws. The descriptive research design was used for this study. The population was drawn from ten (10) secondary schools in FCT. The instrument for data collection comprised of questionnaire titled "Assessment of School Record Management in Secondary Schools in FCT" (ASRMSS). A sample size of eighty respondents from schools was used. Simple percentage was adopted in analyzing the research questions while chi-square was adopted in analyzing the hypotheses. Research findings revealed that the various record books used in schools include: log-book, attendance register, lesson plan, syllabus, staff movement book, visitors' book, admission and withdrawal register, to mention a few. It was also revealed in the findings that most of the records in school are not properly kept. Also, timely supply of school records, availability of funds, teachers' training and proper back up of records were the solutions proffered by respondents. It was however recommended that stakeholders in the school should make use of the school's record books for efficiency purposes. Furthermore, stakeholders should ensure timely update of record materials and finally, delegation and follow-up on record procedures should be given adequate attention by school principals.
\end{abstract}

Keywords: adolescents, attitude, level, Nigeria, parents, secondary school, sex education, stakeholders

LICENSE: This work by Open Journals Nigeria is licensed and published under the Creative Commons Attribution License 4.0 International License, which permits unrestricted use, distribution, and reproduction in any medium, provided this article is duly cited.

COPYRIGHT: The Author(s) completely retain the copyright of this published article.

OPEN ACCESS: The Author(s) approves that this article remains permanently online in the open access (OA) mode.

QA: This Article is published in line with "COPE (Committee on Publication Ethics) and PIE (Publication Integrity \& Ethics)". 


\section{INTRODUCTION}

The school regulatory bodies in Nigeria place a very high importance on school record keeping. School records are official documents, books and files containing essential and crucial information of actions and events, that take place in schools. These records are kept and preserved in the school office for utilization and retrieval of information when needed. Such records are kept by heads of school, principals, teachers, counsellors or administrative staff. The purpose of record keeping and management is to ensure that accurate and proper records of students' achievement and growth, information on school activities and matters that promote efficiency and effectiveness of the school system are kept and maintained (Philip, 2007).

Record keeping is a germane factor in determining the effectiveness and efficiency of the school system. In fact, it is central in the administration of institution of learning because it documents the planning and implementation of appropriate course of service allowing proper monitoring. In conventional paper-based organizations, paper continues to be viewed as the material for records in administrative documentations (Igwoku, 2008). Whichever method is adopted whether paper based or electronic based, the centerpiece is to ensure that efficiency is achieved in the areas of time, cost and resources management. This is evident in the fact that record keeping ensures information can be accessed easily, destroyed routinely when no longer needed, and it enables organizations not only to function on a day to day basis, but also to fulfil legal and financial requirements.

School records occupy strategic position in the effective and efficient organization and administration of the school. This is particularly explained in the assertion of Durosaro (2008) who stated that records are important tools for effective planning and administration of a school. Records are important because they serve as major information tools that sustain the school and aid achievement of educational goals and objectives. Records restore teaching competence and maintain the trend in the history of teaching and learning processes.

Also, not all information can be considered as records until they satisfy such characteristics, genuineness and authenticity; that is the information that records give must be true, correct and original (Egwunyenga 2005). Records must be comprehensive, available, accessible and secured. This implies that records must contain adequate information which is needed for the smooth running of school's activities. School records are grouped into statutory and non-statutory. Statutory records include admission/withdrawal register, attendance register, scheme of work, time-table, logbook, visitors' book (educational policy book), time/movement books, school diary, lesson plan/note for teachers, examination record book, etc. Non-statutory records are cash book, stock book, punishment book, school calendar, inventory book, staff minutes book, school magazine, inspection/supervision report file, confidential report forms and requisition book. Record management is the application of systematic and scientific control of recorded information that is required for the operation of the school. Such control is exercised over the distribution, utilization, retention, storage, retrieval, protection, preservation and final disposition of all types of records within the school. The aim of record management is to achieve the best retrieval and management of school records in the school system and also to improve the efficiency of record making and keeping processes. Record management helps to control the quality and quantity of information that is created in a manner that effectively serves the need of the school (Fasasi, 2004).

Without records there can be no accountability this is in tune with the view of Ibara (2010). He further maintains that quality performance, task accomplishment, and measurable outcomes are increasingly important responsibilities, all of which depend on the accessibility of usable records. Without access to records, it is virtually impossible to determine responsibility for actions and to hold individuals accountable for their actions. 
School record management according to Fasasi (2004) is meant to enhance the performance of secondary school administrators. Adequate record management program co-ordinates and protects an institutions' records, sharpens the effectiveness of records as a management memory which controls the times, equipment and space allocated to records and helps to simplify intra-organizational and communication problems. The management of records in the secondary schools like in any other organization is a cyclic process involving the principals, teachers, students, messengers and cleaners. The bulk of records are handled by principals which are kept manually thus the attendant effect of difficulty in processing, retrieval and utilization of records.

Iwhiwhu (2005) stressed the insufficient quality and quantity of manpower in record management in the school system. He emphasized that manpower is employed without prejudice to qualitative records management. Though this business of record keeping and effective management in the secondary school system has not attained good success due to insufficient provision of facilities, fund and management components however, adequate security, storage facilities and funds are generally recommended for good record keeping and management.

The overwhelming importance of school records, it has been observed that they are poorly kept and managed this is in tandem with the view of Asogwa (2004) which states that records and data generated in the course of execution of legitimate function of an organization or school should be kept and managed properly. School records whether statutory or non-statutory, physical or electronic should be properly kept and managed for utilization and future retrieval. The effective management of school records by principals depends on certain management procedures and functions such as effective supervision, effective leadership, monitoring, provision and training of adequate personnel, records storage and retrieval, discipline and effective communication, delegation of duty, developing record keeping skills and motivation. Babalola, (2007) noted that information and data generated from an effective and efficient records management program aids the school to plan and make useful decisions, preserve facts and figures for future reference, thereby enhancing the efficiency and effectiveness of the organization and administration of the school. The adequate provision of quality manpower, funds and equipment would ensure optimum management of school records. However, inadequate or non-availability of these resources bring about problems and challenges in the efficient and effective management of records. Since all schools are expected to keep records for effective and efficient achievement of educational goals and objectives, it is pertinent to examine whether records are managed properly or not in Federal Capital Territory (FCT) Secondary schools.

School records can be said to comprise all existing and accessible records, books, files and other documents containing useful information that relates to what goes on in the school system (Ololube 2013). These records may also be in the form of reports, letters, memos, pictures, films, journals, diaries, and so on. The importance of secondary education cannot be overemphasized, it enables students to improve on their selfconfidence since they are given opportunity to interact with their peers and adults too. It also enhances independence and helps curb the tendency of children that are highly aggressive during group activities. Students' interactions with their peers and adults help to widen their scope of understanding through cognitive and affective learning. They also gain mastery of the world around them. This in turn makes them relevant and useful through the problem-solving skills they have garnered over the years.

Running the school system, especially middle or secondary school is tasking and demanding, it is worthy of note that students who are churned out as products would serve as images and representatives of the school. 
Hence massive credence should be placed on data preservation because, it is from this that the school can work with its own educational objectives of producing students for higher education and producing students with skills and attributes to be useful in the society (FRN 2004). Oftentimes, schools with poor data bank suffer a great loss because it creates an impression that lasts for quite a while. Data preservation is a pressing concern for schools in all parts of the world. They realize the need to preserve the world's memories. In Nigeria, however, preservation has yet to take its actual place in most academic system. The reason for this is lack of funding.

Caroline (2012) explains formative and summative assessments. She averred that "formative assessment takes place before or during the instruction with the explicit purpose of eliciting evidence that can be used by students and teachers to improve the current learning while summative assessment is a measure of learning at a particular point in time" This means that formative is the pre-assessment done before the end of the exercise while summative is the addition or the total assessment done after the whole exercise. Therefore, some records that constitute formative assessment in schools include: lesson plan, time-table attendance register, log book, students' payment voucher and diary while summative records in schools are termly record/result sheet, termly hostel report, level description and a host of others.

Record management is the systematic control of organizations' records. Record keeping constitutes the arteries that supply life-sustaining blood through the system and sub-systems of organizations and institutions (Nwagwu, 2005). It will definitely be an impossible task to plan and administer any known organization in which records are not kept, or are carelessly or fraudulently kept. The education system as a social organization has numerous sub-systems or levels that are managed to ensure some coherence and continuity. To successfully achieve this, records must be safely kept and managed.

Record management generally concerns the administrative activities that are concerned with achieving cost-effectiveness and efficiency in the creation, maintenance, use and disposal of the records of educational institutions throughout their entire life cycle and in making the information they contain accessible in support of the school business administration (UNESCO, 2005).

\section{OBJECTIVES OF THE STUDY.}

The study aims to address the following;

(1) ascertain the kinds of records that are kept in schools.

(2) determine whether school records are properly managed and retrieved for use.

(3) determine the strategies for improvement of school record management

\section{RESEARCH QUESTIONS.}

The following research questions guided the study

1. What school records are being kept?

2. Are school records properly managed?

3. What strategies can be adopted for the improvement of record management in schools? 


\section{RESEARCH HYPOTHESES.}

Based on the study, the following hypotheses were formulated to be tested:

Ho1: There is no significant difference in the ways of record keeping in secondary schools in FCT.

Ho2There is no significant relationship between proper record management and efficiency of Secondary Schools in FCT.

\section{SIGNIFICANCE OF THE STUDY}

This work will be useful in several spheres, part of which are;

- Helping principals, administrators, teachers, parents, federal ministry of education and the general public in knowing the vital role of school record management of secondary schools.

- Enlightening teachers on how records serve as defensive mechanism in times of trouble and as such they will imbibe the culture of proper records management.

- Helping teachers appreciate the importance of school record management, this will therefore motivate them to cooperate with the principals in documentation of reliable data for quality delivery and it will help shun falsification of school document.

\section{RESEARCH DESIGN}

The descriptive survey design was adopted in this study. This design is considered appropriate because the study variables cannot be manipulated due to proper monitoring but explained as investigated and for its suitability in collection of samples from large population that can be used for generalization. It also allows for the study of the population at one specific time and the difference between the individual groups within the population to be compared.

\section{METHOD OF DATA ANALYSIS}

This data was collected with the use of questionnaire and it was collected in June 2017. It was thereafter analyzed using simple percentage and chi-square. Descriptive statistics including frequencies and percentages was used to answer the research questions while chi-square was used to test the hypothesis. 


\section{RESULTS}

Research question one: What school records are being kept?

Table 1: Available school records.

\begin{tabular}{llllll}
\hline S/N & RECORDS & Available & $\%$ & Not Available & $\%$ \\
\hline 1 & Admission and withdrawal & 10 & 100 & 0 & 0 \\
& register. & & & & 10 \\
2 & Log book. & 9 & 90 & 1 & 0 \\
3 & Attendance register. & 10 & 100 & 0 & 40 \\
4 & National policy on education & 6 & 60 & 4 & 20 \\
5 & Health records from the school & 8 & 80 & 2 & 30 \\
& clinic. & & & & 60 \\
6 & Lesson plan & 7 & 70 & 3 & 0 \\
7 & Disciplinary record & 4 & 40 & 6 & 0 \\
8 & School diary & 10 & 100 & 0 & 0 \\
9 & Staff movement book & 10 & 100 & 0 & 0 \\
10 & Visitor's book & 10 & 100 & 0 & \\
11 & Syllabus. & 10 & 100 & 0 & 16 \\
\end{tabular}

From the table above, it can be extrapolated that a total of ten schools used for this research which represents $100 \%$ of the respondents make use of admission and withdrawal registers, $90 \%$ of the respondents representing 9 schools claimed to have log book which keeps a tab on happenings around the school, while one of the schools could not find theirs.

Furthermore, all the respondents which is indicative of $100 \%$ keep attendance register, 6 schools' representative of $60 \%$ of the respondents have a copy of the National Policy on Education, while the rest representing $40 \%$ do not have it. Eighty percent (80\%) of the respondents keep health records of students, while the rest $(20 \%)$ do not keep student's health records.

Also, 7 (70\%) of the respondents have lesson plans for proper delivery of lessons. Four schools (40\%) of the respondents have disciplinary records while 6 schools (60\%) do not keep disciplinary records. Also, all the respondents have school diaries, the schools keep records of staff movement books. The same can be said of visitor's books, and syllabus 
Research question two: Are school records properly managed?

Table 2: Management styles

\begin{tabular}{llllll}
\hline S/N & RECORDS & $\begin{array}{l}\text { Available but } \\
\text { not properly } \\
\text { utilized. }\end{array}$ & \multicolumn{2}{l}{$\begin{array}{l}\text { Available and } \\
\text { properly } \\
\text { utilized. }\end{array}$} \\
& & 5 & 50 & 5 & 50 \\
\hline 1 & Admission and withdrawal register. & 5 & 77.7 & 2 & 22.3 \\
2 & Log book. & 7 & 90 & 1 & 10 \\
3 & Attendance register. & 9 & 83.3 & 1 & 16.6 \\
4 & National policy on education. & 5 & 62.5 & 3 & 37.5 \\
5 & Health records from the school clinic. & 5 & 0 & 7 & 100 \\
6 & Lesson plan & 0 & 25 & 3 & 75 \\
7 & Disciplinary record & 1 & 70 & 3 & 30 \\
8 & School diary & 7 & 0 & 10 & 100 \\
9 & Staff movement book & 0 & 0 & 10 & 100 \\
10 & Visitor's book & 0 & 50 & 5 & 50 \\
11 & Syllabus. & 5 & & 50 & \\
\hline
\end{tabular}

From the table above, of the 10 schools that make use of admission and withdrawal register, only 5 of the school which represents $50 \%$ properly utilize it in the sense that they do not only take records of total enrolment, they also take records of the students that were withdrawn from the school. However, the remaining $50 \%$ do not properly utilize the admission and withdrawal register as some only take records of enrolment while leaving out withdrawal.

Meanwhile, out of the 9 schools that claimed to have log books, 7 schools which represents $77.7 \%$ do not properly utilize theirs because, many pages of the book were either left blank or having few lines of record of events. This denotes that there are either no school activities for that day or there were few activities for the day which is unrealistic. However, 2 schools representing $22.3 \%$ keep adequate record of daily happenings in the school as this was obvious in the level of meticulous report given for various school days. Of those who keep registers, only one which indicates $10 \%$, timely records it, by marking students for mornings and afternoons. The remaining $90 \%$ (9 schools) failed to keep timely record of the attendance register, this is obvious in the way in which some class teachers have not touched their diaries in days, those who even touched theirs wait till afternoon before marking the full attendance, hence making it difficult to ascertain which students were present in the morning but were however not available in the afternoon and vice versa due to various reasons.

Five out of the six schools that have a copy of the policy, representative of $83.3 \%$ fail to properly utilize it, as they have not gone through it let alone act on its content. But the rest (16.6\%) make proper use of it. Also, 5 representing $62.5 \%$ out of the 8 schools do not properly utilize health records, while the rest representing $37.5 \%$ make proper use of health records.

In the same vein none of the teachers have an up-to-date lesson plan. However, among the four schools that keep disciplinary records, only one representing $25 \%$ makes use of this record while the remaining $3(75 \%)$ 
fail to utilize the information from this report. Additionally, only 7 of them representing $70 \%$ do not properly utilize it as they fail to enter the weekly records of topics taught in the diary. The remaining $30 \%$ however takes this record.

Also, all the schools keep records of staff movement books and they all properly utilize this as they make use of it in the monthly payment of salaries and other benefits and allowances. The same can be said of visitor's books, all the schools keep record of visitors as they use this in analyzing in part how many enquiries were made or how many people showed interest in the school. Lastly all the respondents make use of syllabus, but only $50 \%$ of them follow it while the rest pick topics at random.

Research Question Three: What strategies can be adopted for the improvement of record management in schools?

Table 3: Strategies that can be adopted for the improvement of record management in schools

\begin{tabular}{llll}
\hline S/N & ITEMS & SA & \% \\
\hline 1 & Timely supply of school records. & 38 & 47.5 \\
2 & Adequate funds should be made available for record keeping purpose. & 59 & 73.75 \\
3 & Training should be done for teachers particularly in electronic record & 69 & 56.25 \\
& keeping & 72 & 90 \\
4 & Vaults should be made available for adequate back-up of records. & 90 \\
5 & External hard drives should be made available for adequate back-up of & 72 & 90 \\
& records. & & \\
\hline
\end{tabular}

It can be extrapolated from the table above, that 38 (47.5\%) strongly agreed that there should be timely supply of school records as this would improve record keeping. Fifty-nine (59) respondents representing $73.75 \%$ argued that adequate funds should be made available for record keeping purpose. Furthermore, 69 respondents representing 56.25\% maintained that training should be done for teachers particularly in electronic record keeping. Finally, 72 respondents opined that vaults and external hard drives should be made available for adequate backup of records. 


\section{HYPOTHESIS ONE}

Ho: There is no significant difference in the ways of record keeping in secondary schools in FCT.

$\mathrm{H1}_{1}$ : There is significant difference in the ways of record keeping in secondary schools in FCT

Table 4: Difference in the ways of record keeping

\begin{tabular}{llll}
\hline No of row & No of column & Calculated value & Table value (5\%) \\
\hline 11 & 2 & 34.49 & 18.40 \\
\hline
\end{tabular}

\section{DECISION}

Since the calculated value of $x^{2}$ is greater than the table value of $x^{2}$ (34.49>18.397), null hypothesis is rejected and the alternative hypothesis which says school records are not properly kept is accepted. It can thus be inferred that the records, keeping of records in the schools of focus leaves much to be desired. This is because the results gotten from the research instruments show that records such as admission/withdrawal register, attendance register, log book and a host of others are not properly kept. Therefore, efforts should be made to properly and adequately keep records in schools as this will engender efficiency.

\section{HYPOTHESIS TWO}

Ho: There is no significant relationship between proper record management and efficiency of Secondary Schools in FCT

$\mathrm{H}_{1}$ : There is significant relationship between proper record management and efficiency of Secondary Schools in FCT.

Table 4: Relationship between proper record management and efficiency

\begin{tabular}{llll}
\hline No of row & No of column & Calculated value & Table value (5\%) \\
\hline 11 & 2 & 50.51 & 18.40 \\
\hline
\end{tabular}

\section{DECISION}

Since the calculated value of $x^{2}$ is greater than the table value of $x^{2}(50.51>18.397)$, null hypothesis is rejected and the alternative hypothesis which says there is significant relationship between proper record management and efficiency of Secondary Schools in FCT is accepted. It can thus be inferred that the records, there is a thick linkage between efficiency rate and record keeping, this means that efficiency and effectiveness in school is tied to proper record keeping. Therefore, since records are not properly kept, it can be concluded that the efficiency level of schools is not commendable. Therefore, efforts should be made to properly and adequately keep records in schools as this will engender efficiency.

\section{DISCUSSION}

Results revealed that school records that are currently kept in secondary school include; admission and withdrawal register, logbook, attendance register, school time table, diary, visitors' book, exam records, time movement book 
and a host of others. This is in line with the view of Olubebe (2013) which highlights the kind of records kept in schools.

The results also revealed that school records are not properly kept as most of the seemingly kept records are not properly and effectively kept. This is in agreement with the view of Chifwepa, (2011) which opined that poor record keeping can be linked to policy summersault.

Results also unveiled some strategies for improving on school records management in schools which include: timely supply of relevant school records, making funds available for record keeping purpose, training of personnel who keep records on a daily basis in school and finally providing proper back-up device for school records. This is equally in tandem with the assertion of (Olubebe, 2013).

In conclusion, results from the hypotheses revealed that school records are not properly kept, it also revealed that there is significant relationship between proper record management and efficiency of Secondary Schools in FCT.

\section{RECOMMENDATIONS}

Based on the findings of this study, the following recommendation were arrived at:

1. Principals, Vice-principals and teachers should properly utilize the following schools records which were found to be currently kept in secondary school such as admission and withdrawal register, log book, attendance register, school timetable, diary of work, visitors books, exam record book, time movement book, a copy of National policy on Education and lesion note/plan.

2. Principals, vice-principals and teachers should ensure that these records are kept and updated timely and effectively. Records such as diaries, attendance register and others should not be left to pile up until they become difficult or cumbersome to record.

3. Principals should adequately delegate and monitor tasks that require record keeping, and there should be proper follow up on delegated tasks.

\section{CONCLUSION}

There are a lot of benefits attached to record keeping as it could engender efficiency and effectiveness in schools. However, lack of proper record management can be attributed to paucity of funds, lack of record keeping materials, lack of motivation on the part of teachers and a host of others.

Therefore, this research links a relationship between proper record keeping or effective record management and efficiency and effectiveness in schools. From the findings of the study and observation of the researchers, the following conclusion can be drawn:

1. Accurate records keeping in the school is very important and as such has a great influence on the management and administrative performance of the principals and teachers.

2. The principals who adhere to acceptable and idea administrative practices in keeping of school records would engender improved standard of school records management in the school system.

3. Effective school records management is very vital in general school management. In other words, principals and teachers must of necessity ensure accurate school records in the pursuit and accomplishment of school goals and objectives. 


\section{REFERENCE}

Adeleke, A. (2001) Management: Concepts and Application. Lagos, Nigeria. Concept publication limited

Adesina, S. A. (2004). Some aspects of school management. Ibadan: Education Industries (Nig) Ltd.

Bosah, H, O. (2011). Dynamics of Educational Administration and Management. Awka: Meks publishers Ltd. Records keeping in Nigeria Schools (pp. 19-47). In Ndu, N., Ocho, L.O \& Okeke, B.S. (Eds)

Caroline, W. (2012). Teachers formative and summative assessments. Journal of Research and Development Connections. 3(2): 6-15.

Chifwepa, V. (2014). Managing records at school level. National Education Statistical Information Systems. Retrieved, October 15, 2014 fromhttp://www.adeanet.org/ad eaPortal/adea/downloadcenter/NESIS/Erecords-021065.pdf.

Davar, R.S. (2009). Principles of Management. Bombay Progressive Cooperation private Ltd. (pp. 6-24)

Durosaro, D.O. (2002). Management of school records. In the Craft of Educational Management. The Craft of Educational Management (pp. 138-152). Illorin: Indemac.

Egwunyenga,B,O. (2009). The influence of record keeping on administrative performance of school administrators. Ebonyi: Elites Publishers Ltd.

Ehiametor, E.T. \& Aderounmu, W.O. (1985). Introduction to administration of school in Nigeria. Mindex Publishers. Lagos: (pp. 15-19)

Eke, E. (2000). School Administration and Management. Education Cycle 4, pp. 12-12.

Eno, A.O. (2008). A handbook of educational foundations. Jos: Nigerian Challenges Press.

Eresimadu, FN,j. \& Nduka (2007) Educational Administration and Planning. Nsukka: Optimal Computer Solution

Fasasi, O. (2010). School record and effective administration. Educational Journal, 2(3)3-11

Fasasi, Y.A. (2004). School records keeping: A strategy for management of Nigerian secondary education institutions. Ilorin Journal of Education. 5 (2): 8-33

Gama, U. G. (2010). A Survey of Records Management Practices in Circular Primary School in Metropolitan. Local Government Area (MLGAs) of Kano State. Journal of Information Studies, 10(1\&2), 23-30.

Idoko, A.A. (2005). Understanding School management. Makurdi: Ugo Printing Press.

Jones, D. (2003). Educational Journal, 4(2) Database management in educational sector. Lena, M. (2006). International Journal of Public Information Systems, vol 2006:1-11

Okpetu, S. A., \& Peretomode, O. (2005). School Records in Educational Administration. Peretomode (Ed). Introduction to Educational Administration, Planning and Supervision. Lagos, Nigeria: Joja Educational Research and Publishers.

Oluwole, M.U. (2007). School Management and supervision. Makurdi: Destiny Ventures.

Osakwe, N. R. (2011). Management of School Records by Secondary School Principals in Delta State, Nigeria. The Social Sciences, 6(1), 40-44.

Ukeje, B.O., Akabogu, G.C. \& Ndu, A. (1992). Educational administration. Enugu: Fourth Dimension 